\title{
Haur Galur Youth Organization Training in Understanding of Basic and Supporting Components of IoT Technology
}

\author{
ERWANI MERRY SARTIKA, DANIEL SETIADIKARUNIA, AAN DARMAWAN, \\ AUDYATI GANY, NOVIE THERESIA BR. PASARIBU, VINCENSIUS NUGROHO
}

Program Studi Teknik Elektro Universitas Kristen Maranatha

Email: erwani.ms@eng.maranatha.edu, erwanimerry@gmail.com

Received 02 May 2020 | Revised 22 May 2020 | Accepted 30 May 2020

\begin{abstract}
Internet of Things (IoT) is a conceptual technology that aims to complement the benefits of internet connectivity that connected continuously. IoT is a paradigm that states that each object can be used as a device that can identify, sense, as long as it is connected to the telecommunications network and provides communication with other equipment that connected to the internet. PAR (Participatory Action Research) is a method that involves interested parties in assessing the actions being carried out to make changes for the better. Youth Organization is a place for the development of the young generation that grows from awareness and responsibility, and officially is supported by the government to develop the potential that exists in the area. Electrical Engineering Study Program of Universitas Kristen Maranatha supports Karang Taruna Haur Galur Sukagalih Village, Bandung City, by providing knowledge, competencies, and skills, especially in the Internet of Things technology. Through this training obtained the results that indicate an increase of 30\%, specifically about the knowledge of the nature of capacitors, and knowledge of WiFi. While for some knowledge questions such as LDR, pull-up, and some symbols, a quite good correct answer percentage of around $40 \%$ (from all participants) was obtained. The motivation of participants to progress and develop is seen from $100 \%$ of participants felt training needed to be continued again.
\end{abstract}

Keywords: Internet of Things (IoT), Participatory Action Research (PAR), Karang Taruna

\section{INTRODUCTION}

The internet is known as a network that connects humans and information. The internet is developing rapidly from its initial concept, because not only computers and telephones can be connected, even various other objects that can send and receive data through the internet which is often referred to as the Internet of Things (IoT) (Meutia, 2017). 
Internet of Things (IoT) is a concept that aims to expand the benefits of continuously connected internet connectivity (Atoasi, 2018). This development provides many opportunities on various sides of people's lives (Meutia, 2017). The Indonesia IoT Forum predicts that the Indonesian IoT market potential in 2020 will reach around 35 billion dollars (Kusumawati, Winarko, Wahab, \& Pradono, 2017).

IoT is a paradigm that states that each object can be used as a device that can identify, sense, as long as it is connected to a telecommunications network and can communicate with other equipment connected to the internet (Informatika, Penelitian, Daya, \& Pos, 2016). For this reason, beginners need a basic understanding of the supporting components that are learned and used in the implementation of IoT.

The development of industry towards industry 4.0 requires the community to be able to follow the development of these technologies with the aim that the job seeker community is not excluded from competition for work. In the case of community empowerment in order to be able to follow technological developments, efforts can be made to provide continuous training and guidance. This guidance can be carried out by universities in the form of community service.

Youth Organization is a place for the development of young people who grow up with awareness and responsibility that officially receives support from the government to develop the potential that exists in the area. The community formed this organization as a place for young people to develop themselves, grow, and develop based on awareness and social responsibility of, by, and for the young generation, oriented towards achieving social welfare for the community.(Batubara, 2019).

Karang Taruna Haur Galur, Sukagalih Village, Bandung, has a program to equip its members with a variety of knowledge, competencies, and skills. One of them is to equip its members with knowledge and understanding of the development of the Internet of Things technology, which is currently overgrowing. On this occasion, the Electrical Engineering Study Program of Universitas Kristen Maranatha strongly supported the intention of Karang Taruna Haur Galur, Sukagalih, Bandung to help provide knowledge, competencies, and skills, especially Internet of Thing technology. For the Electrical Engineering Study Program of Universitas Kristen Maranatha, the Karang Taruna fostering activity is an opportunity to share knowledge that realized in community service activities appropriate with Karang Taruna Haur Galur's needs in developing potential in its area and is expected to improve social welfare for its members.

\section{METHODS}

The assistance method used is Participatory Action Research (PAR), a method that actively involves stakeholders in assessing ongoing actions to make changes for the better. PAR consists of three words that are always related to one another, namely participation, research, and engagement (Afandi, 2015).

The initial mapping was carried out in a participatory manner with the community by exploring the problems experienced by Karang Taruna Haur Galur Sukagalih, Bandung. From the initial meeting with the management of Karang Haur Galur Youth Organization, it was found that there was a need for members of the Youth Organization to follow technological developments so as not to be excluded in the competitive world of work. The activity of equipping members to be able to follow technological developments and implement them is one of the work 
programs of Karang Taruna Haur Galur, which coincides with one of the programs being developed at that time, namely growing hydroponic plants that can be monitored easier using IoT. The meeting with the management of Youth Organization Haur Galur is shown in Figure 1. This need is then used as the basis for holding of IoT technology training for youth organizations by the Electrical Engineering Study Program of Universitas Kristen Maranatha so that the problems can be solved together (Participatory).
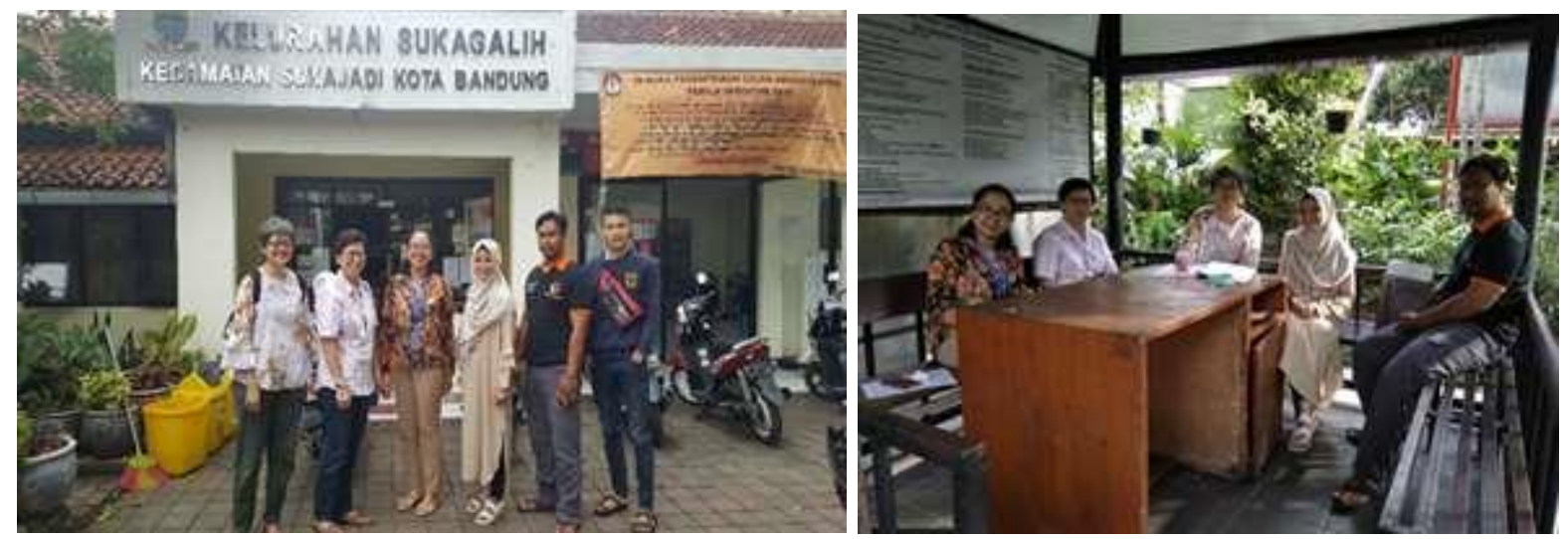

Figure 1. Meeting with the Haur Galur Youth Organization Officer

Furthermore, planned activities/actions for the development of youth groups in the form of technological literacy improvement. Literacy is arranged so that the material given is easier to understand, and there is an increase in the ability of literacy participants considering that they are still beginners. Understanding of basic and supporting components of IoT technology are the main objectives of the process of increasing literacy participants' abilities.

The presentation of literacy is given in the form of demonstrations and experiments. The demonstration method is a teaching method by demonstrating that it can not be separated from the verbal explanation by the instructor. Although in the process of demonstration, the literacy participants only pay attention, the instructor can present more concrete lesson material in expository and inquiry learning strategies $(\mathbf{W}, \mathbf{2 0 0 9})$. While the experimental method is a way of giving the material by conducting experiments to prove themselves hypotheses/theories learned. Through the experimental method, participants can practice scientific thinking (Sagala, 2005). Joint reflection with the community formulates the theorization of social change. Based on the results of research, community learning processes, and actions that have been carried out, the test result data is used to reflect all the processes and results obtained (from beginning to end) (Afandi, 2015).

\section{RESULTS AND DISCUSSION}

The Community Service Activities was carried out on March 30, 2019, at the Electrical Engineering Computer Laboratory, Universitas Kristen Maranatha. All participants filled out the attendance list and received a literacy module in the form of learning materials about IoT, as shown in Figure 2. The activity was attended by 24 members of Karang Taruna Haur Galur Sukagalih, Bandung. 

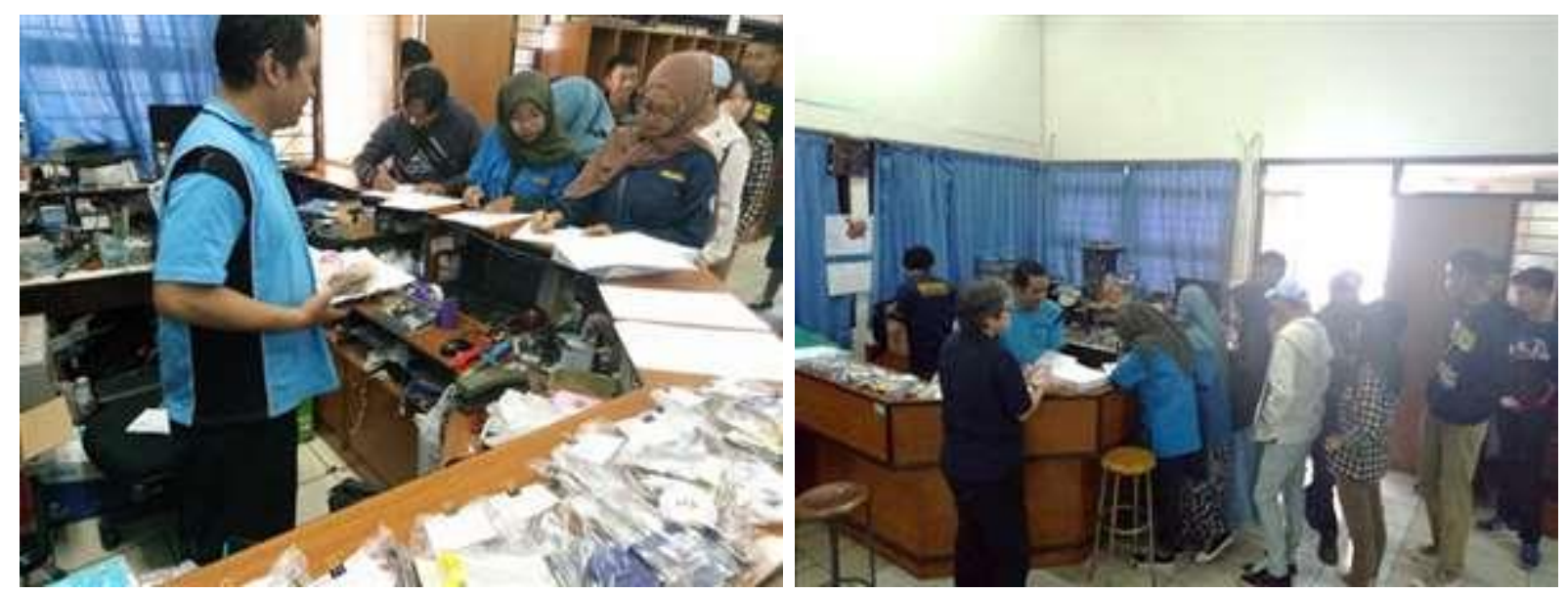

Figure 2. Participants are filling in the attendance list and receiving the IoT module

Karang Taruna members who participated in activities consisted of $58.3 \%$ women and $41.7 \%$ men were shown in Figure 3. The age of activities participants varied in age categories, namely: ages $10-19$ years (62.5\%), ages $20-29$ years (20.8\%), ages $30-39$ years $(8.3 \%)$, ages $40-49$ years $(4.2 \%)$, and ages $50-59$ years $(4.2 \%)$ as shown in Figure 4 . The background level of education varies, starting from $12.5 \%$ of graduates of junior high schools (SMP), $75 \%$ graduates of senior high schools / vocational high schools (SMA / SMK), and $12.5 \%$ of graduates of undergraduate degrees (S1) as shown in Figure 5. Whereas in Figure 6 are the work charts of activities participants consisting of students (37.5\%), unemployed $(20.8 \%)$, Private Employees (12.5\%), Self-employed (12.5\%), Daily Workers $(8.3 \%)$ and Housewives $(8.3 \%)$. With diverse backgrounds in gender, age, level of education, and occupation, this becomes a challenge in community service activities to design appropriate training so that all participants can absorb the material presented.

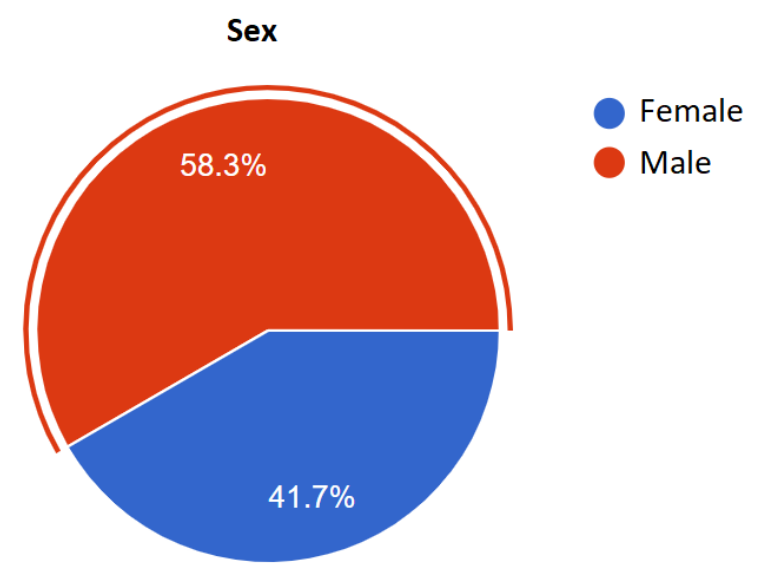

Figure 3. Sex Pie Graph Participants in Literacy Development of IoT Technology Karang Taruna Haur Galur 
Haur Galur Youth Organization Training in Understanding of Basic and Supporting Components of IoT Technology

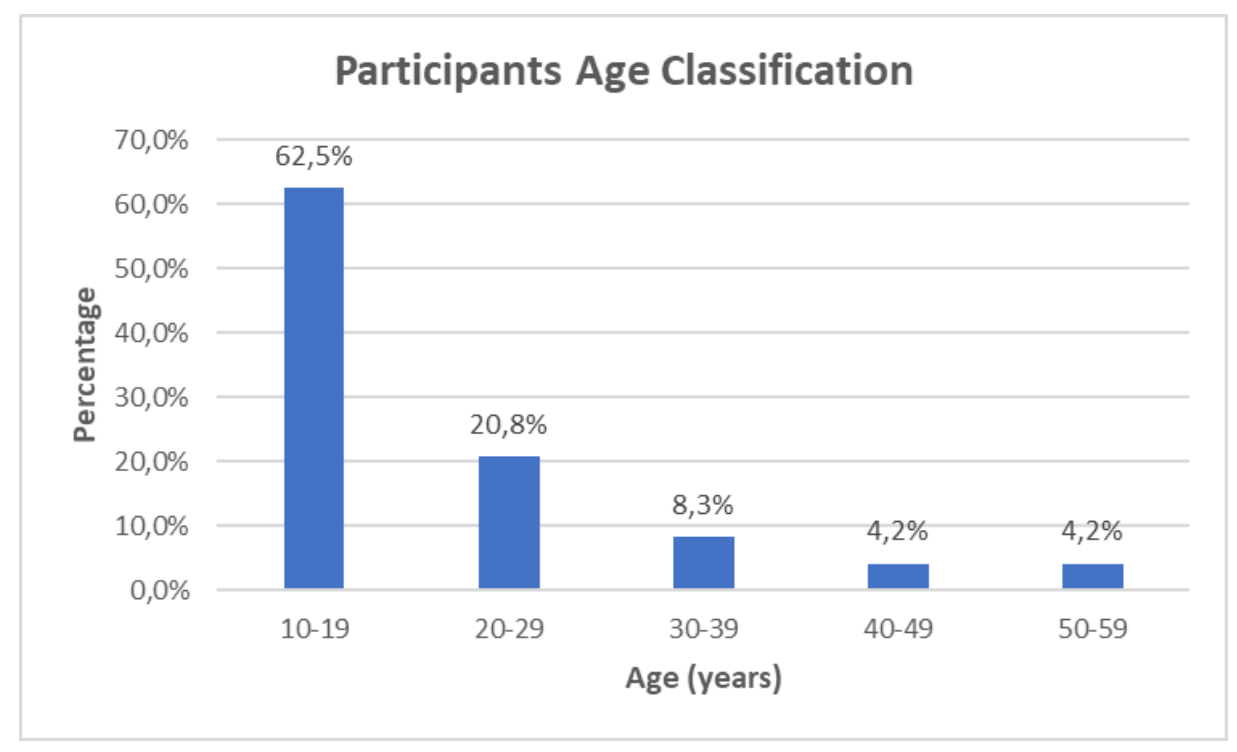

Figure 4. Age Bar Graph Participants in the Literacy Development of IoT Technology Karang Taruna Haur Galur

The Latest Education Participants

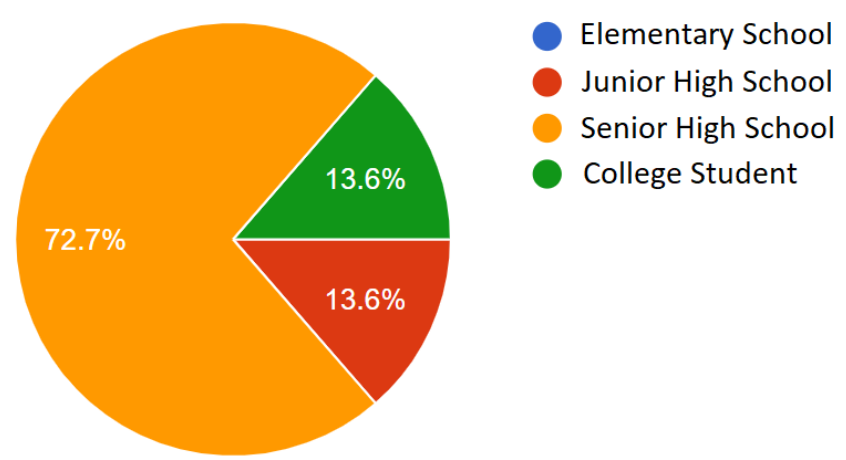

Figure 5. The Latest Education Pie Chart of Literacy Participants in the Development of IoT Technology Karang Taruna Haur Galur

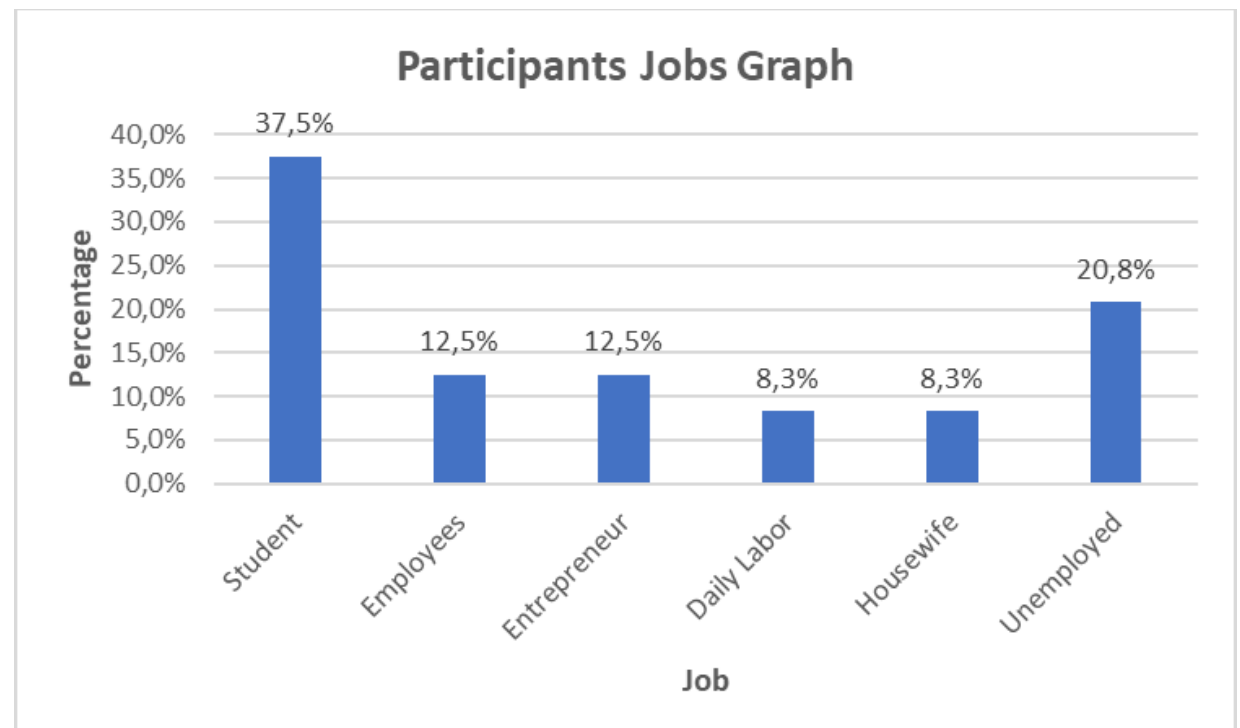

Figure 6. Bar Graph Work of Participants in Literacy Development of IoT Karang Taruna Haur Galur Technology

Reka Elkomika - 5 
Through the initial test (pretest) as shown in Figure 7, it can be seen the initial ability level of participants in understanding of basic and supporting components of IoT technology is an average of $66.66 \%$. The material that was understood in the initial test were some questions about the definition of the internet, the definition of IoT and its benefits, the properties of resistors, and the definition of WiFi with an understanding capability of more than $75 \%$. However, from questions related to the knowledge of programming language used, passive components, electric currents, capacitor properties, and switch properties obtained results below $50 \%$.
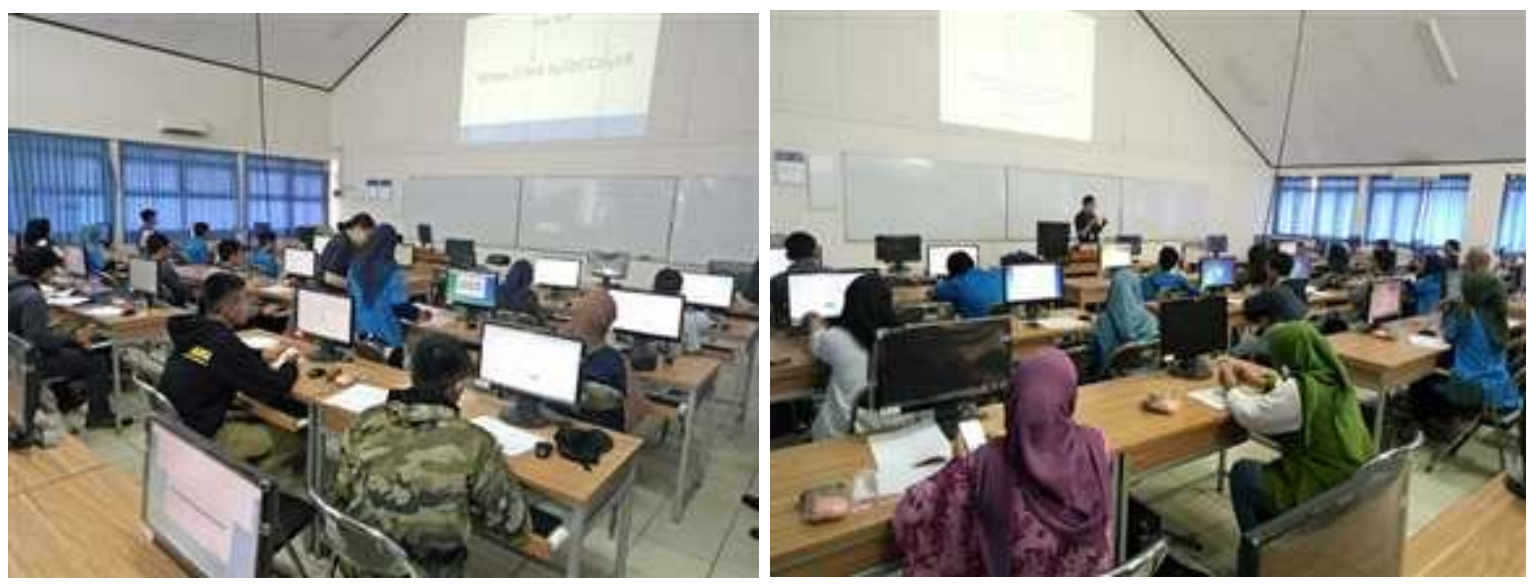

Figure 7. Conditions when participants took the Pre Test and IoT lecture

The stages of implementation in community service begin with the presentation of the material provided in this literacy in the form of a basic theory of the Internet of Things (IoT) technology in the form of definitions, history, concepts, applications and issues of IoT, then proceed with the basic knowledge of electricity and electronics components ( $R, C$, Switch, LED). Then interspersed with the practice of reading and using components that have been described, as shown in Figure 8.

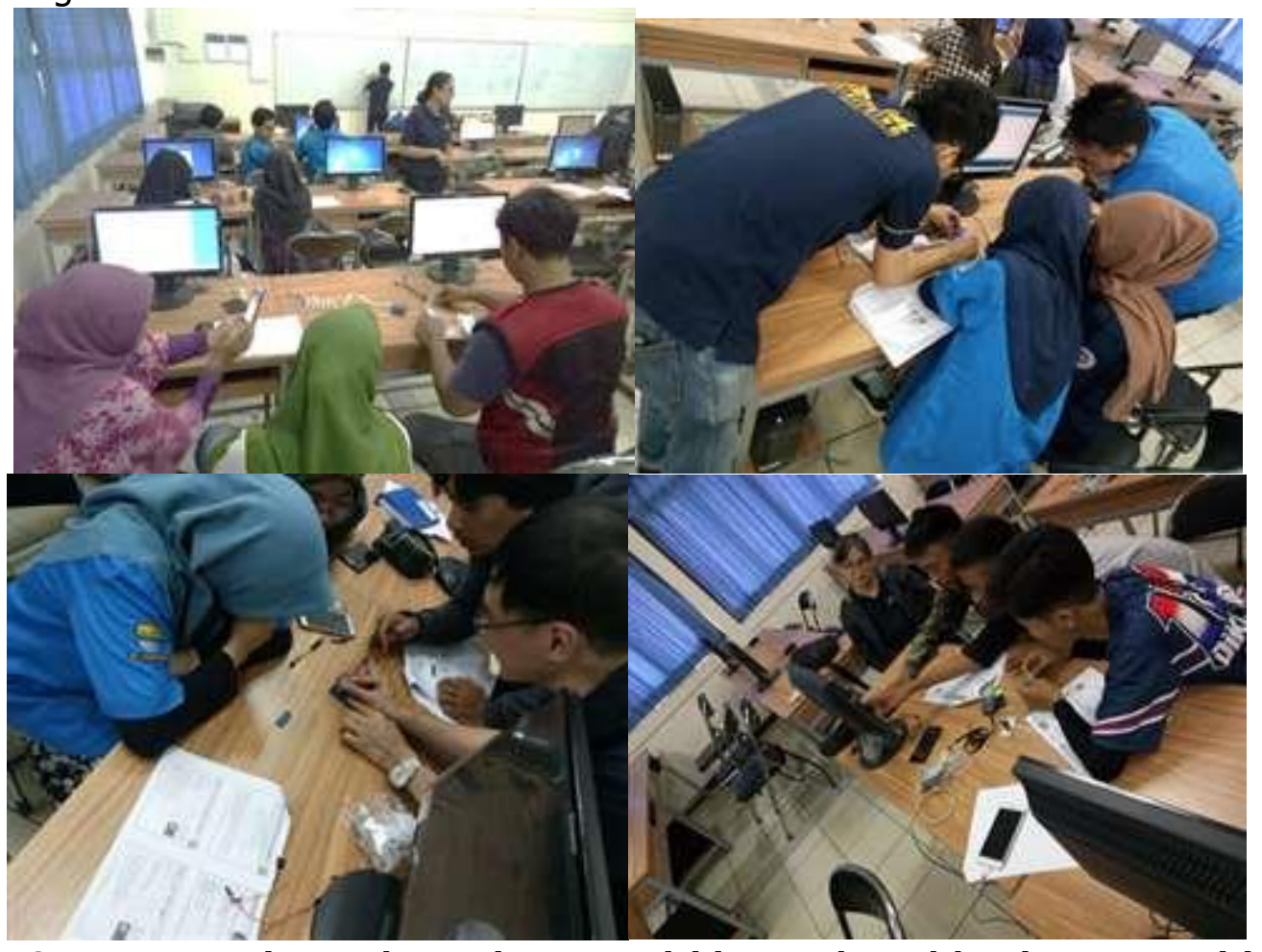

Figure 8. Demonstration and Experiment Activities conducted by Literacy participants 
Haur Galur Youth Organization Training in Understanding of Basic and Supporting Components of IoT Technology

The material continued about IoT controller hardware (ESP8266-12), Arduino IDE software, and Arduino IDE Programming language (C-based). Furthermore, the practice of using some of the supporting components provided for the application of the Internet of Things technology. The first practice (I) is given to participants in the form of Digital I/O \& Serial Communication (4 modules), Analog I/O \& LDR Light Sensor (1 module), LM35 IC Temperature Sensor (1 module), and Infrared and Photo Diode (1 module).

Explanation of the next material is the ESP8266-12 Wifi Module. The second practice (II) is given 3 modules for setting and configuring ESP8266-12 mode in the form of Station mode (as a client), Access Point mode, and Web Server (as a server). This is a form of action on the PAR (Participatory Action Research) method based on demonstration and experimentation as conducted during the practice of reading components, first and second practice. The lecture method is still combined to clarify the practice being carried out.

At the end of community service, participants are given a final test (post-test), which aims to measure the capability increasing, as well as evaluating the implementation of community service using a questionnaire which aims to measure the quality of service delivery. While the participants participated in this activity, participants were guided by instructors and assistants from lecturers and students of the Electrical Engineering Study Program of Universitas Kristen Maranatha.

Final test results showed some significant improvements (increased 30\%), especially in the knowledge of the nature of the capacitors, and knowledge of WiFi. While some questions that did not exist during the initial test (pretest) such as LDR knowledge, pull-ups, and some symbols obtained a pretty good percentage of correct answer (around $40 \%$ of all participants were able to answer correctly), from the results of this final test, it can be concluded that there was a sufficient increase in the knowledge of participants about IoT technology, although it cannot be directly above $50 \%$ for questions that had never been asked during the pretest.

The survey results show that $65 \%$ agreed the training was in line with expectations, $65 \%$ strongly agreed the training increased knowledge, $78 \%$ agreed the material presented was easy to understand by adding demonstrations and experiments, $52 \%$ agreed the training was useful, $52 \%$ strongly agreed the training material provided interesting, $57 \%$ agreed the quality of the training was good, $57 \%$ agreed the speaker was able to deliver the material well and clearly, $70 \%$ agreed the literacy was timely, $57 \%$ strongly agreed that the literacy facility was satisfactory, $61 \%$ strongly agreed the assistant was ready and deftly helpful, $65 \%$ strongly agree that overall literacy is going well and $100 \%$ of participants feel the training needs to be continued. In addition to the implementation of community service literacy, on March 30, 2019, a cooperation agreement was also signed in the form of community service activities between the Electrical Engineering Study Program and the Management of the Haur Galur Youth Organization, Sukagalih Village, Bandung City as shown in Figure 9. At the end of the activity, a photo session was also held, as shown in Figure 10. At present, Karang Taruna Haur Galur is still in establishing the hydroponic planting process, and for the use of the IoT technology is still in the design process so that it cannot be reported in this paper. In the future, while preparing members of Youth Organization ready to use IoT technology, another literacy is being prepared so that the use of IoT technology can be monitored via smartphones. 

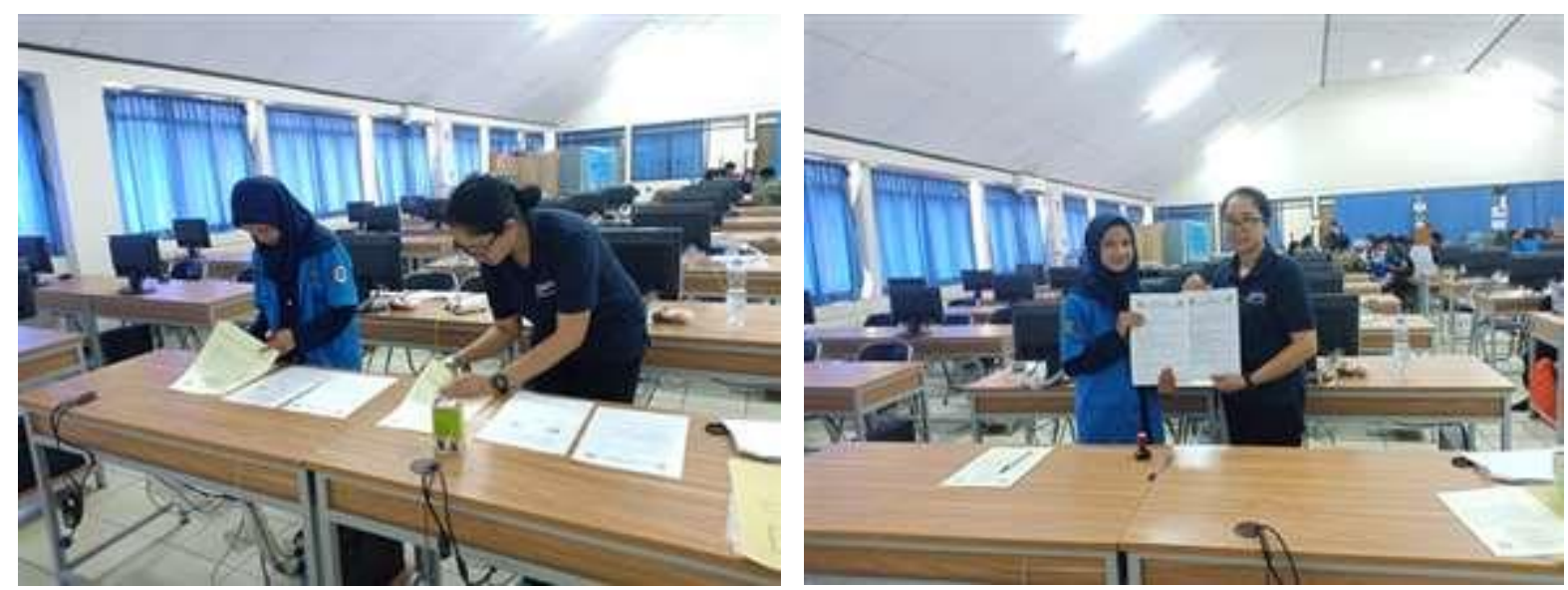

Figure 9. Photograph of Evidence of the Signing of Collaboration in Community Service activities between the Electrical Engineering Study Program of Universitas Kristen Maranatha and the Haur Galur Youth Organization, Sukagalih Village, Bandung City.

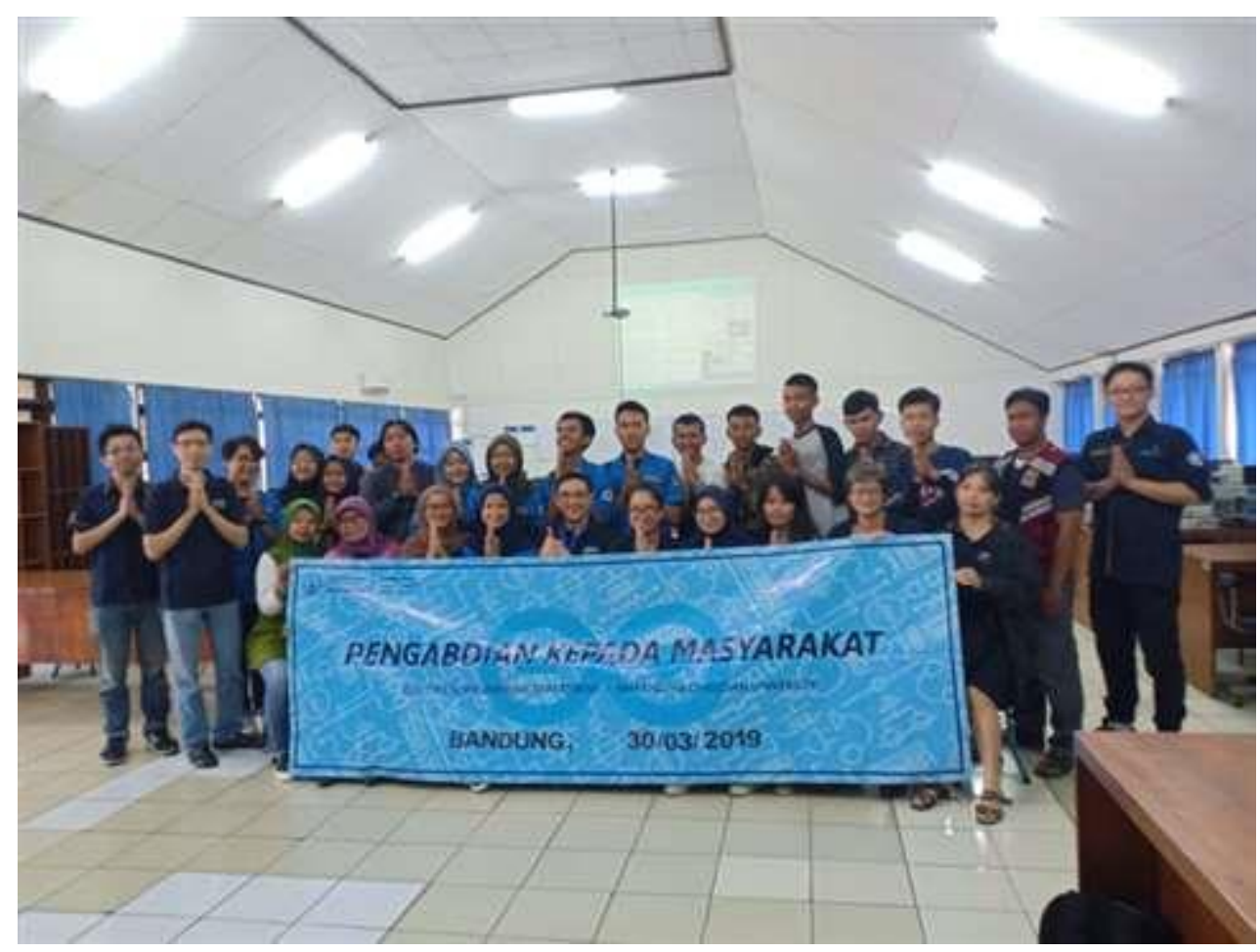

Figure 10. Group Photos of all IoT Literacy Participants, Instuctors, and Assistants

\section{CONCLUSION}

The implementation of Participatory Action Research was successfully implemented through mentoring actions for members of Karang Taruna Haur Galur because of the need for IoT technology for hydroponic monitoring as participation of the Electrical Engineering Study Program of Universitas Kristen Maranatha. From the training given to the Youth Organization Haur Galur, there was an increase in the knowledge of the participants by $30 \%$, and when viewed from the motivation of the participants to further improve their abilities, it was apparent 
that $100 \%$ of the training participants wanted to continue the coaching of IoT. The coaching method with demonstration and experimentation techniques is very influential so that participants can more easily understand the material provided (78\%).

\section{LIST OF REFERENCES}

Afandi, A. (2015). Modul Participatory Action Research (PAR) untuk Pengorganisasian Masyarakat (Community Organizing).

Atoasi, S. (2018). Analisis penerapan smart city dan internet of things (iot) di indonesia, (November).

Batubara, J. P. Peraturan Menteri Sosial Republik Indonesia Nomor 25 Tahun 2019 tentang Karang Taruna (2019).

Informatika, K., Penelitian, P., Daya, S., \& Pos, P. (2016). Implementasi Internet Of Things Untuk Sektor Kesehatan. Puslitbang Sumber Daya, Perangkat, dan Penyelenggaraan Pos dan Informatika Badan Penelitian dan Pengembangan Sumber Daya Manusia Kementrian Komunikasi dan Informatika.

Kusumawati, D., Winarko, B., Wahab, A., \& Pradono, W. (2017). Analisis Kebutuhan Regulasi Terkait dengan Internet of Things Analisis Kebutuhan Regulasi Terkait dengan Internet of Things The Analysis of The Required Regulation of Internet of Things. Buletin Pos Dan $\begin{array}{lllll}\text { Telekomunikasi, } & 15 & \text { No. } & 2 & \text { (December), }\end{array}$ https://doi.org/10.17933/bpostel.2017.150205

Meutia, E. D. (2017). Dampak Sosial Internet of Things. In Seminar Nasional dan Expo Teknik Elektro 2017, ISSN.2088-9984 (pp. 102-106).

Sagala, S. (2005). Konsep dan Makna Pembelajaran.

W, S. (2009). Metode Demonstrasi. 